\title{
Comparative Analysis of Nutritional Sources on the Morpho-Physiological Characteristics of Mung Bean (Vigna radiata)
}

\author{
Zubair Aslam ${ }^{1}$, Ali Ahmad ${ }^{1, *}$, Muhammad Idrees ${ }^{2}$, Naeem Iqbal ${ }^{2}$, Ghulam Akbar ${ }^{3}$, Umaro Ali $^{4}$, Mu- \\ hammad Usman Ibrahim ${ }^{1}$, Korkmaz Bellitürk ${ }^{5}$, Shoaib Naeem ${ }^{1}$, Muhammad Nawaz ${ }^{6}$, Mehwish Na- \\ deem $^{7}$, Muhammad Waqas ${ }^{1}$, Wajeeh Ur Rehman ${ }^{1}$, Muhammad Sajjad ${ }^{1}$, Samiullah $^{8}$, Yousuf Akram ${ }^{1}$ \\ ${ }^{1}$ Department of Agronomy, University of Agriculture Faisalabad, 38000, Pakistan. \\ ${ }^{2}$ Plant Physiology Section, Agronomic Research Institute, Ayub Agricultural Research Institute, Faisalabad, Pakistan. \\ ${ }^{3}$ Department of Biochemistry, University of Agriculture Faisalabad, 38000, Pakistan. \\ ${ }^{4}$ Department of Plant Breeding and Genetics, Ghazi University, Dera Ghazi Khan, Pakistan. \\ ${ }^{5}$ Department of Soil Science and Plant Nutrition, Faculty of Agriculture, Tekirdag Namık Kemal University, Suleymanpasa Te- \\ kirdag, Turkey. \\ ${ }^{6}$ Vegetable and Oil Seed Section, Agronomic Research Institute, Faisalabad, Pakistan. \\ ${ }^{7}$ Department of Botany, University of Agriculture Faisalabad, 38000-Pakistan. \\ ${ }^{8}$ Department of Plant Pathology, University of Agriculture Faisalabad, 38000, Pakistan.
}

\begin{abstract}
How to cite this paper: Zubair Aslam, Ali Ahmad, Muhammad Idrees, Naeem Iqbal, Ghulam Akbar, Umaro Ali, Muhammad Usman Ibrahim, Korkmaz Bellitürk, Shoaib Naeem, Muhammad Nawaz, Mehwish Nadeem, Muhammad Waqas, Wajeeh Ur Rehman, Muhammad Sajjad, Samiullah, Yousuf Akram. (2020) Comparative Analysis of Nutritional Sources on the Morpho-Physiological Characteristics of Mung Bean (Vigna radiata). International Journal of the Science of Food and Agriculture, 4(3), 314-322.

DOI: 10.26855/ijfsa.2020.09.011
\end{abstract}

Received: August 22, 2020

Accepted: September 13, 2020

Published: September 22, 2020

*Corresponding author: Ali Ahmad, Department of Agronomy, University of Agriculture Faisalabad, 38000, Pakistan.

Email: aliahmadsial2643@gmail.com

\begin{abstract}
Nutrients deficiency is a major threat against Vigna radiata (mung bean) growth. The effects of nutrients can be mitigated by vermicompost, vermi-tea and chemical fertilizers. With the objective to combat the nutrients deficiency, an experiment was conducted in Riverm Kompost Vermikompost Tarım Hay. Mak. San. ve Ltd. Şti. Suleymanpasa, Tekirdag, Turkey under field conditions. In field four different states of fertilizers $\left[\mathrm{F}_{0}\right.$ : Control (No fertilizer application); $\mathrm{F}_{\mathrm{vc}}$ : Solid vermicompost @ 5 ton/ha; $\mathrm{F}_{\mathrm{vt}}$ : vermi-tea @ 4\%; $\mathrm{F}_{\mathrm{c}}$ : Chemical fertilizers (N\&P) @ 80-60 kg/ha] were applied in mung bean. The plants were harvested 45 days after sowing and the evaluation was done on the basis of various morphological (seed germination, root length, shoot length, root fresh weight, shoot fresh weight, root dry weight, shoot dry weight and number of leaves) and physiological parameters [relative water contents (RWC), chlorophyll contents and membrane stability index (MSI)]. The randomized complete block design (RCBD) with three replicates and least significant difference test were used at 5\% probability level. The obtained results indicated that significant impact of natural and synthetic fertilizers on morpho-physiological characters of Vigna radiate were recorded as compared to control but foliar application of $4 \%$ vermi-tea treatment showed maximum morphological and physiological performance on Vigna radiate.
\end{abstract}

\section{Keywords}

Deficiency, Mung Bean, Morphological, Physiological, Vermi-Fertilizers

\section{Introduction}

Mung bean (Vigna radiata L.) is an essential pulse crop belongs to leguminous family. Its cultivation area is about 6 million hectares along the whole globe especially China, Pakistan, India, Bangladesh due to drought tolerance ability and short growth cycle of 70 days. It is cheap and has good nutritional value so it is common to be consumed in almost 
all countries [1]. It contains protein, vitamins, minerals, dietary fibers and large amount of bioactive compounds such as peptides, poly phenols and polysaccharides [2]. Nutritionally, mung bean contributes a significant for improvement of human health and as well as nitrogen fixation in agro-ecosystem [3].

Vermicomposting is the process of synthesis of compost from organic material by the action of earthworms living in the soil with microbial flora [4]. Vermicomposted material containing Perionyx excavatus, Lampito mauritii, Eisenia foetida, Eudrilus eugeniae, can be transformed into environment friendly organic fertilizer containing large amount of nutrients and with the microbial enzyme action on vermicompost increases the easy absorbtion by plant roots [5]. Vermicompost increases the soil porosity, oxygen availability, infltration of water and also maintains normal temperature of soil for the improved growth and yield of plants [6]. Seed treatment by vermitea (VT) has positive effect on earlier germination and development of crop [7]. Vermitea revealed growth regulating properties over the morphological traits for instance, length of shoot. Additionally, liquid vermicompost provide balanced nutrients to stimulate the root development and also enhance "humic substance" that influence nutrient assimilation and promote the root development of plant [8]. It has been found that microbial activity in vermitea resultantly produce considerable amount of plant growth regulators (PGRs) for instance gibberellins, IAA and cytokinins. Excessive content of humic acid was produced in vermicomposting that have significant impact on plant development [9].

Chemical fertilizers ( $\mathrm{N}$ and $\mathrm{P}$ ) are integral components that construct the structural, physiological and biochemical roles of plant to contribute crop development [10]. Nitrogen is an essential nutrient for normal growth yield enhancement of plant and it is also an integral component of amino acids in protein form [11]. Synthesis of enzymes, proteins, RNA, DNA and other cellular components are only occurred under the availability of $\mathrm{N}$ nutrients in plants that promote primary growth and sustain functionality of other important tissues of plant. Along with $\mathrm{N}$ nutrient, the three more macronutrient is Phosphorous $(\mathrm{P})$ and it is mainly intake by the plant from rhizosphere. The $(\mathrm{P})$ availability encourages the primary growth of root, blooming and maturity of plant [12]. However, it has been revealed that application of (P) fertilizer usually has large influence on yields of crop and its scarcity constrains the plant response to other nutrients. Combined effect of ( $\mathrm{N}$ and $\mathrm{P}$ ) nutrients enhance length and morphology of root, root-shoot biomass and also improve branching plasticity of plant [13]. Research revealed that mungbean yield and quality could improve by the use of balanced fertilizers.

Keeping in view the above literature the trial had following objective: To compare the effects of natural and synthetic fertilizers on the morphology and physiology of mung bean crop.

\section{Materials and methods}

\subsection{Analysis of Soil}

The clay loam soil was used for the trial. The soil analysis was carried out at Soil Science Laboratory No. 1, Department of Soil Science and Plant Nutrition, Faculty of Agriculture, Tekirdag Namık Kemal University, Suleymanpasa, Tekirdag, Turkey and its results are shown below in (Table 1).

Table 1. Analyzed clay loam soil parameters and their results

\begin{tabular}{ccc}
\hline Parameters & Results & Unit \\
\hline pH & 7.63 & $\%$ \\
Salt & 0.06 & $\%$ \\
Lime & 5.77 & \\
ISBA & 53.00 & $\%$ \\
Organic matter & 1.46 & $\%$ \\
Total nitrogen (N) & 0.07 & Ppm \\
Phosphorus (P) & 30.43 & ppm \\
Potassium (K) & 235.19 & Ppm \\
Calcium (Ca) & 532.41 & Ppm \\
Magnesium (Mg) & 308.54 & Ppm \\
Iron (Fe) & 6.54 & Ppm \\
Copper (Cu) & 2.06 & Ppm \\
Zinc (Zn) & 3.36 & Ppm \\
Manganese (Mn) & 13.02 & \\
\hline
\end{tabular}




\subsection{Analysis of vermicompost and vermi-tea}

The pH EC (dS/m), OM (\%), C/N, N (\%), $\mathrm{P}_{2} \mathrm{O}_{5}(\%), \mathrm{K}_{2} \mathrm{O}(\%), \mathrm{Ca}(\%), \mathrm{Mg}(\%), \mathrm{Fe}(\%), \mathrm{S}(\%)$, and heavy metals Cd (mg/kg), $\mathrm{Ni}(\mathrm{mg} / \mathrm{kg}), \mathrm{Pb}(\mathrm{mg} / \mathrm{kg}), \mathrm{Hg}$ (mg/kg), $\mathrm{Cr}(\mathrm{mg} / \mathrm{kg}), \mathrm{Sn}$ (mg/kg), of vermicompost and vermi-tea were measured which are shown below in (Table 2 and Table 3).

Table 2. Chemical analysis of vermicompost and vermi-tea

\begin{tabular}{|c|c|c|c|c|c|c|c|c|c|c|c|}
\hline Treatments & pH & EC (dS/m) & OM (\%) & $\mathbf{C} / \mathbf{N}$ & N (\%) & $\mathbf{P}_{2} \mathrm{O}_{5}(\%)$ & $\mathrm{K}_{2} \mathrm{O}(\%)$ & Ca (\%) & Mg (\%) & Fe $(\%)$ & S (\%) \\
\hline Vermicompost $\left(\mathrm{F}_{\mathrm{VC}}\right)$ & 7.20 & 2.35 & 53.00 & 13.20 & 1.80 & 1.18 & 0.90 & 3.55 & 0.65 & 0.55 & 0.42 \\
\hline Vermi-tea $\left(\mathrm{F}_{\mathrm{VT}}\right)$ & 6.50 & 3.00 & 3.00 & 2.40 & 5.45 & 5.22 & 3.88 & 7.00 & 2.23 & 2.45 & 1.76 \\
\hline
\end{tabular}

Table 3. Chemical analysis for heavy metals of Vermicompost and Vermi-tea

\begin{tabular}{ccccccc}
\hline Treatments & $\mathbf{C d}(\mathbf{m g} / \mathbf{k g})$ & $\mathbf{N i}(\mathbf{m g} / \mathbf{k g})$ & $\mathbf{P b}(\mathbf{m g} / \mathbf{k g})$ & $\mathbf{H g}(\mathbf{m g} / \mathbf{k g})$ & $\mathbf{C r}(\mathbf{m g} / \mathbf{k g})$ & $\mathbf{S n}(\mathbf{m g} / \mathbf{k g})$ \\
\hline Vermicompost $\left(\mathrm{F}_{\mathrm{VC}}\right)$ & 0.55 & 7.35 & 32.55 & 1.40 & 8.10 & 0.07 \\
Vermi-tea $\left(\mathrm{F}_{\mathrm{VT}}\right)$ & 0.07 & 1.80 & 2.65 & 0.02 & 0.55 & 0.002 \\
\hline
\end{tabular}

\subsection{Experimental Structure}

This research work was conducted in Riverm Kompost Vermikompost Tarım Hay. Mak. San. ve Ltd. Şti. Suleymanpasa, Tekirdag, Turkey under field conditions in 2019. The format of examination was structured in totally randomized plan with three duplicates in the period of kharif. Four different treatments of fertilizers $\left[\mathrm{F}_{0}\right.$ : Control (No fertilizer application); $\mathrm{F}_{\mathrm{vc}}$ : Solid vermicompost @ 5 ton/ha; $\mathrm{F}_{\mathrm{vv}}$ : vermi-tea @ 4\%; $\mathrm{F}_{\mathrm{c}}$ : Chemical fertilizers (N\&P) @ 80-60 kg/ha] were applied to mung bean. The layout of experiment was designed in completely randomized design with three replicates in the season of kharif. The following data about different aspects of mung bean plants were collected: 1). With the help of meter rod root length and shoot length $(\mathrm{cm})$ were noted; 2$)$. Root and shoot fresh weight (g plant $\left.{ }^{-1}\right)$ : Roots were separated from the base part of the shoot, and their fresh weight (g) was noted; 3). Root dry weight: For the dry weight of root $\left(\mathrm{g} \mathrm{plant}^{-1}\right.$ ) separated root matter was incubated at $70^{\circ} \mathrm{C}$ in an oven for 4 days to obtain constant dry weight. These dried roots were weighed in grams; 4). Shoot dry weight: For shoot dry weight (g plant ${ }^{-1}$ ) separated shoot material was incubated in an oven for four days at $70^{\circ} \mathrm{C}$ for making constant dry weight. This dried material of shoots was measured in terms of grams [14]; 5). Number of leaves: overall number of leaves present on the plant was noted and for statistical analysis their average was determined; 6). Membrane Stability Index (MSI) \%: For the determination of leaf membrane stability index leaf samples $(0.1 \mathrm{~g})$ were kept in-distilled water into two sets. In one experiment it was given $40^{\circ} \mathrm{C}$ for half hour and applying conductivity meter its conductivity measured $\left(C_{1}\right)$. In another experiment it was placed at $100^{\circ} \mathrm{C}$ in water bath for $15 \mathrm{~min}$, and its conductivity $\left(\mathrm{C}_{2}\right)$ was also determined [15]. Following is the formula for the calculation of MSI.

MSI $=1-\left(\mathrm{C}_{1} / \mathrm{C}_{2}\right) \times 100$

7). Leaf chlorophyll contents (SPAD Value): leaves chlorophyll components were measured by applying SPAD instrument (model SPAD-502; Minolta Corp., Ramsey, N.J.); 8). Relative water contents (RWC) test: For the determination of RWC the shoot second leaf from the mung bean plant was cut with a blade and immediately its fresh weight was noted. Leaves were dipped in the distilled water in the plastic bags to determine the turgid weight (TW). Under dim light environment around $20 \mathrm{~m} \mathrm{~mol} \mathrm{~m}^{-2} \mathrm{~s}^{-1}$ in the laboratory conditions in natural fluctuating temperature the leaves were imbibed for 24 hours by keeping in plastic bags. These imbibed leaves were weighed again after the completion of imbibitions and then turgid weight was measured. After measuring this turgid weight these leaves material was incubated in oven at $70^{\circ} \mathrm{C}$ for three days. After three days weight of these dried leaves sample was done in grams. With carefully handled precision of $0.0001 \mathrm{~g}$ all these measurements were performed on a standard analytical level. The percentage RWC was determined by applying the values of DW, FW and TW in the following equation

RWC $(\%)=[($ fresh weight - dry weight $) /$ (turgid weight - dry weight) $] * 100$

\subsection{Statistical Analysis}

By applying Fisher's analysis of variance (ANOVA) technique obtained results were measured. Least Significant Difference (LSD) test was applied $(\mathrm{p}<0.05)$ to compare the significant treatment means using Statistics version 
8.1(Analytical Software, 1985-2005) and according to [16] and sigma plot was utilized for charts.

\section{Results and discussion}

\subsection{Germination \% age}

The effect of vermicompost, vermi-tea and chemical fertilizer on seed germination was observed in which maximum seed germination $>90 \%$ was obtained with the addition of solid vermicompost. However, by applying chemical fertilizer on mung bean seed average seed germination was obtained. Whereas the use of vermi-tea for seed germination showed lowest among three treatments effect on mung bean seed. The vermi-tea was applied foliarly at 15 days after crop germination that is why less seed germination was attained in this treatment. Under controlled conditions where no additional ingredient was added the minimum seed germination was observed (Table 4, Figure 1). These results on seed germination also correlates with the findings of Chuhan et al. [17], who observed the similar significant effects of vermicompost on seed germination and obtained increased production of different vegetable crops. In an investigation conducted by Tomati et al. [18], the effect of chemical fertilizer with an amount of 80-60 kg/ha have not greatly increased the seed germination of crops. In contrast, under controlled conditions without fertilizer and other growth promoting components the seed germination of crops reduced among all other treatments.

\subsection{Root length (cm)}

The effect of vermitea, vermicompost and chemical fertilizer on roots was observed. Among these additional growth enhancers the effect of vermi-tea on the root length of mung bean was reported maximum as shown in (Table 4, Figure 1). In investigation of Tomati et al. [18], who demonstrated that the impact of vermi-tea on leguminous crops significantly enhanced the root initiation and biomass. Respectively, Kumar et al. [3] found these results resemble to the findings of Siddiqui et al. (2008) who observed the enhanced root growth by applying vermi-tea to the various plants.

\subsection{Shoot Length}

The effect of vermi-tea was significant on shoot length. With the addition of vermi-tea an increase in the length of shoot had been detected in comparison to the other treatments as shown in (Table 4, Figure 1). With the application of solid vermicompost and chemical fertilizer relatively less shoot length was observed. The similar result was also obtained by the findings of Keeling et al. [20] who observed increased growth on shoot length with the addition of vermi-tea. In another investigation it was observed that vermi-tea facilitate the supply of nutrients in the plant roots stimulating growth and also promotes the growth of shoot [13].

\subsection{Root fresh weight}

The effect of vermicompost, vermi-tea and chemical fertilizer on root fresh weight have been observed. The maximum root fresh weight was observed by vermi-tea (Table 4, Figure 1). The chemical fertilizer and vermicompost treated mung bean crops expressed almost equal root fresh weight. The lowest root fresh weight was observed by control crop in which no additional ingredient was added. These results are resemble to the findings of Sebastian and Selvaraju [21], who observed the maximum root fresh weight by using vermi-tea than vermicompost and chemical fertilizers. In another investigation mung bean yield was seen to be increased by applying vermicompost which increased the activity of soil microbial organisms and improved the soil fertility [21].

\subsection{Shoot fresh weight}

Similar to root fresh weight vermi-tea treated crops have maximum shoot fresh weight. As compared to chemical fertilizer vermicompost treated mung bean plants have greater shoot fresh weight. Here also control expressed minimum shoot fresh weight like root fresh weight as illustrated in (Table 4, Figure1). These consequences are very similar to the investigations of Waseem et al. [22] who found the more shoot fresh weight by using vermi-tea as compared to other additional growth enhancers. This is because of growth regulators present in the vermi-tea which regulate and promote plant growth. Vermi-tea consists of calcium $(\mathrm{Ca})$, nitrogen $(\mathrm{N})$, phosphorus $(\mathrm{P})$, rhizobacteria and growth and soil organic material. 


\subsection{Root dry weight}

Vermi-tea treated crops exhibited maximum root dry weight as compared to other components (Table 4, Figure 1). Among vermicompost and chemical fertilizer root dry weight was more for vermicompost. Controlled mung bean crop's (without fertilizer) root dry weight was observed minimum. This result closely relates to the findings of Lawlor [23] who used vermi-tea to the plants. Absorption of nutrients by the roots was incredibly increased that enhances the root mass and density.

\subsection{Shoot dry weight}

The effect of vermicompost, vermi-tea and chemical fertilizer on shoot dry weight was observed and the maximum weight was obtained by the vermi-tea applied crops (Table 4, Figure 1). The shoot dry weight of vermicompost is greater than the shoot dry weight of chemical fertilizer. Ansari and Sukhraj [24] found that the lowest weight was gained by the control (without fertilizer) which is similar to our results.

\subsection{Chlorophyll contents}

Chlorophyll contents have been measured in these experiments and the maximum chlorophyll was found in the crop of mung bean treated with vermi-tea. Chemical fertilizers have no significant enhancement in the chlorophyll contents and found less chlorophyll as compared to vermicompost (Table 4, Figure 1). The amount of chlorophyll was found minimum in the control area crops and Meghvansi et al. [25] had found the similar conclusions.

\subsection{Number of leaves}

The number of leaves was counted in each treatment crops and the maximum leaves were found in the vermi- tea applied crops (Table 4, Figure 1). Vermicompost treated crops of mung bean produced more leaves as compared to the chemical fertilizer and minimum number of leaves was obtained by without any fertilizer's addition (control). Aslam and Ahmad [26] found that the use of vermicompost and vermiwash expressed a good effect as compared to chemical fertilizer as well as control on the okra yield.

\subsection{Membrane stability index}

The effect of different growth promoters on crop membrane stability index was analyzed and the maximum membrane stability index was observed by vermi-tea, however others crops treated with vermicompost and fertilizer also expressed a significant membrane stability index (Table 4, Figure 1). The lowest membrane stability index was observed by crop in which no additional growth promoting ingredient was added (control) [23].

\subsection{Relative water contents}

The relative water contents in all treatment crops were found to be high and the maximum proportion of water contents was observed in vermi-tea treated mung bean crops (Table 4, Figure 1). The water contents were found relatively less in the crops grown without fertiliz. Aslam et al. [27] demonstrated that vermicompost and vermi-tea had good results on crops because these nutritional sources contain all macro and micro nutrients. When relative water contents are decreased then drought condition is produced and this reduction in water content decreased the plant vigour and growth [28].

Table 4. Mean sum of square of morpho-physiological parameters as influenced by different organic and inorganic amendments in mungbean

\begin{tabular}{|c|c|c|c|c|c|c|c|c|c|c|c|}
\hline $\begin{array}{c}\text { Mean sum } \\
\text { of square }\end{array}$ & $\begin{array}{c}\text { Germination } \\
\text { \%age }\end{array}$ & $\begin{array}{c}\text { Root } \\
\text { length } \\
\text { (cm) }\end{array}$ & $\begin{array}{l}\text { Shoot } \\
\text { length } \\
\text { (cm) }\end{array}$ & $\begin{array}{l}\text { Root } \\
\text { fresh } \\
\text { weight } \\
\text { (g) }\end{array}$ & $\begin{array}{l}\text { Shoot } \\
\text { fresh } \\
\text { weight } \\
\text { (g) }\end{array}$ & $\begin{array}{c}\text { Root } \\
\text { dry } \\
\text { weight } \\
\text { (g) }\end{array}$ & $\begin{array}{l}\text { Shoot } \\
\text { dry } \\
\text { weight } \\
\text { (g) }\end{array}$ & $\begin{array}{c}\text { Number } \\
\text { of leaf }\end{array}$ & $\begin{array}{c}\text { Chlorophyll } \\
\text { contents } \\
\text { (SPAD Value) }\end{array}$ & $\begin{array}{l}\text { Membrane } \\
\text { stability index } \\
\text { (MSI) \% }\end{array}$ & $\begin{array}{c}\text { Relative } \\
\text { water con- } \\
\text { tents } \\
\text { (RWC) \% }\end{array}$ \\
\hline Replication & 34.33 & 2.58 & 3.58 & 5.145 & 0.64 & 0.09 & 0.29 & 0.58 & 0.33 & 14.08 & 10.33 \\
\hline Treatment & $99.19^{* *}$ & $52.97^{* *}$ & $69.19^{* *}$ & $26.07^{* *}$ & $62.61^{* *}$ & $1.10^{* *}$ & $3.03^{* *}$ & $22.083^{* *}$ & $130.22^{* *}$ & $182.22^{* *}$ & $71.86^{* *}$ \\
\hline Error & 18.11 & 1.13 & 2.36 & 3.86 & 1.17 & 0.03 & 0.43 & 0.25 & 2.22 & 8.30 & 7.11 \\
\hline
\end{tabular}

* Significant at 0.05 level of significance. 

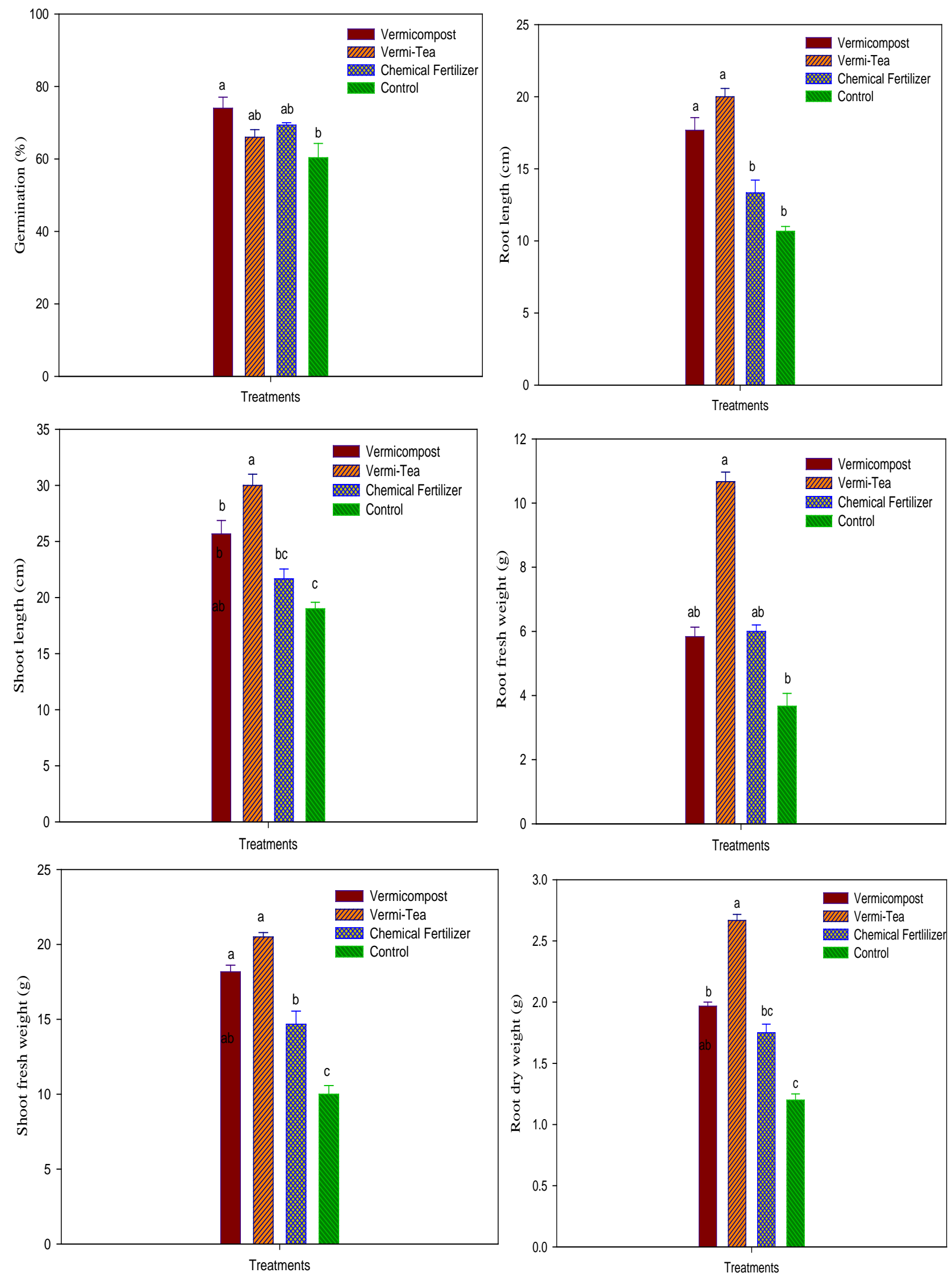

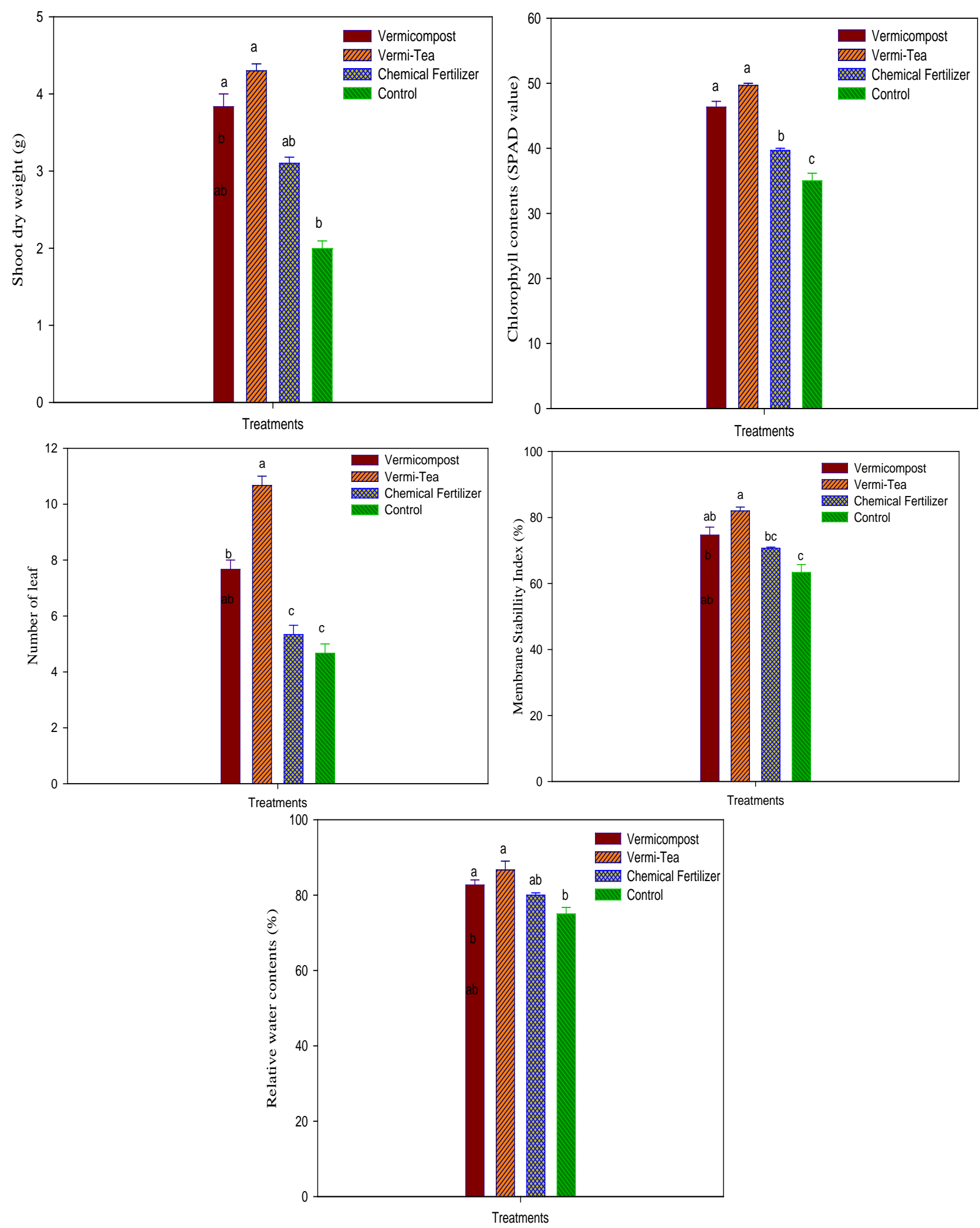

Figure (1a, b, c, d, e, f, g, h, I, j, k). Effects of vermicompost, vermi-tea and chemical fertilizer on morpho-physiological characteristics of mung bean. 


\section{Conclusion}

Vermi-fertilizers and chemical fertilizer significantly increased all of the above said parameters of mung bean as compared to control but foliar application of $4 \%$ vermi-tea treatment showed maximum morphological and physiological performance of mung bean. So it is recommended the use of vermi-tea to the farmers for better crop production.

\section{Acknowledgments}

The current experiment was conducted at Riverm KompostVermikompostTarım Hay. Mak. San. ve Ltd. Şti.Suleymanpasa, Tekirdag, Turkey under field conditions under the project titled "Vermicomposting: an Agricultural Waste Management Technology” under Pak-Turk Researchers Mobility Grant Program Phase-II, vide letter No. (Ph-II-MG-9)/PAK-TURK/R\&D/HEC/2018 and Second project NRPU-HEC project no. 7527/Punjab/NRPU/R\&D/HEC/2017_ Vermicomposting: A resourceful organic fertilizer to improve agriculture production and soil health] financially supported by Higher Education Commission of Pakistan.

\section{References}

[1] Dahiya PK, Linnemann AR, Van BMA, Khetarpaul JS, Grewal NRB, \& Nout MJR. (2015). Mung bean: Technological and nutritional potential. Crit Rev Food Sci Nutr, 55: 670-688.

[2] Popkin ABLS \& Ng SW. (2012). Global nutrition transition and the pandemic of obesity in developing countries. Nutr Rev, 70: 3-21.

[3] Kumar A, Mosa KA, Ji L, Kage U, Dhokane D, Karre S, Madalageri D, \& Pathania N. (2018). Metabolomics-assisted biotechnological interventions for developing plant-based functional foods and nutraceuticals. Crit Rev Food Sci Nutr, 58: 1791-1807.

[4] Zularisam A, Zahir WZ, ZakariaI, Syukri MM, Anwar A, \& Sakinah M. (2010). "Production of Biofertilizer from vermicomposting Processes of Municipal Sewage Sludge”. J Appl Sci, 7: 580-584.

[5] Parthasarthi K \& Ranganathan LS (2002). Supplementation of presumed vermicast with NPK enhances growth and yield in Leguminous crops (Vignamungo and Arachishypogaea). J Carr Sci, 2: 35-41.

[6] Arora VK, Singh CB, Sidhu AS, \& Thind SS. (2011). Irrigation, tillage and mulching effects on Soybean yield and water productivity in relation to soil texture. Agr Water Manag, 4: 563-568.

[7] Sampedro L, Zas R, \& Domínguez J. (2010). Vermicompost enhances germination of the maritime pine (Pinuspinaster Ait.). New Forests, 3: 387-400.

[8] Canellas L, Olivares FL, Okorokova FAL, \& Façanha AR. (2002). Humic acids isolated from earthworm compost enhance root elongation, lateral root emergence, and plasma membrane H+-ATPase activity in maize roots. Plant Physiol, 4: 1951-1957.

[9] Chen Y \& Aviad T. (1990). Effects of humic substances on plant growth. Humic substances in soil and crop sci: Selected readings, (humicsubstances), 161-186.

[10] Sinclair TR \& Vadez V. (2002). Physiological traits for crop yield improvement in low N and P environments. Plant Soil, 245: 1-15.

[11] Mozumder SN, Salim M, Islam N, Nazrul MI, \& Zaman MM. (2003). Effect of Bradyrhizobium inoculation at different nitrogen levels on summer mungbean (Vignaradiata L.). Asian J Plant Sci, 2: 817-822.

[12] Sompong U, Nakasathien CS, \& Srinives P. (2010). Inheritance of seed phytate in mungbean (Vigna radiate L.). Euphytica. 171: 389-396.

[13] Song CJ, Ma KM, Qu LY, Liu Y, Xu XL, \& Fu BJ. (2010). Interactive effects of water, nitrogen and phosphorus on the growth, biomass partitioning and water-use efficiency of Bauhinia faberi seedlings. J Arid Environ, 9: 1003-1012.

[14] Nour AM, Weibel DE, \& Tood GW. (1978). Evaluation of root characteristics in grain sorghum. Agron. J., 70: $217-218$.

[15] Premachandra GS, Saneoka H, \& Ogata S. (1990). Cell membrane stability an indicator of drought tolerance as affected by applied nitrogen in soybean. J Agric Sci, 115: 63-66.

[16] Steel RGD, Torrie JH, \& Dickey D. (1997). Principles and procedures of statistics: A Biometrical Approach. 3rd Ed. McGraw Hill Book Co, New York.

[17] Chuhan PS, Suman B, \& Manmeet S. (2017). Urea, DAP, Potash and their mixture on seed germination and seedling growth of Maize (Zea mays L.). Res J Agr \& For Sci, 2: 1-4.

[18] Tomati U, Grappelli A, \& Galli E. (1988). The hormone-like effect of earthworm casts on plant growth. Biol. Fertil Soils 4: 288-294.

[19] Siddiqui Y, Sariah M, \& Razi I. (2008). Trichoderma-fortified compost extracts for the control of Choanephora wet rot in okra production. Crop Prot, 27: 385-390.

[20] Keeling AA, McCallum KR, \& Beck CP. (2003). Mature green waste compost enhances growth and nitrogen uptake in wheat (Triticum aestivum L.) and oilseed rape (Brassica napus L.) through the action of water-extractable factors. Bioresour Technol, 
2: $127-132$.

[21] Sebastian A \& Selvaraju P. (2017). Influence of temperature of production environment on seed quality and storability of rice genotypes. Inter J Curr Microbiol Appl Sci, 6: 4273-4284.

[22] Waseem, M, Athar HR, \& Ashraf M. (2006). Effect of salicylic acid applied through rooting medium on drought tolerance of wheat. Pak J Bot, 4: 1127-1136.

[23] Lawlor DW. (2002). The limitation to photosynthesis in water-stressed leaves: stomata versus metabolism and the role of ATP. Ann Bot, 89: 1-15.

[24] Ansari A \& Sukhraj K. (2010). Effect of vermiwash and vermicompost on soil parameters and productivity of okra in Guyana. Afr J Agr Res, 14: 1794-1798.

[25] Meghvansi MK, Khan MH, Gupta R, Gogoi HK, \& Singh L. (2012). Vegetative and yield attributes of okra and nagachilli as affected by foliar sprays of vermiwash on acidic soil. J crop imp, 1(4): 520-531.

[26] Aslam, Z \& Ahmad A. (2020). Effects of Vermicompost, Vermi-tea and chemical fertilizer on morpho-physiological characteristics of maize (Zea mays L.) in Suleymanpasa District, Tekirdag of Turkey. J Innov Sci., 6(1): 41-46.

[27] Aslam Z, Ahmad A, Bellitürk K, Iqbal N, Idrees M \& Rehman WU, Akbar G, Tariq M, Raza M, Riasat S and Rehman SU (2020). Effects of vermicompost, vermi-tea and chemical fertilizer on morpho-physiological characteristics of tomato (Solanum lycopersicum) in Suleymanpasa District, Tekirdag of Turkey. Pure Appl Biol, 9 (3): 1920-1931.

[28] Halder KP \& Burrage SW. (2003). Drought stress effects on water relations of rice grown in nutrient film technique. Pak $J$ Biol Sci, 5: 441-447. 